Article

\title{
Immunological Trajectories of White Blood Cells from Adolescence to Adulthood: Description and Determinants
}

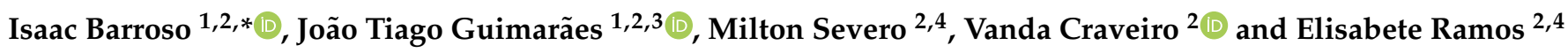 \\ 1 Department of Clinical Pathology, São João University Hospital Centre, 4200-319 Porto, Portugal; \\ jtguimar@med.up.pt \\ 2 EPIUnit, Instituto de Saúde Pública, University of Porto, 4050-091 Porto, Portugal; \\ severo.milton@gmail.com (M.S.); vandacraveiro@gmail.com (V.C.); eliramos@med.up.pt (E.R.) \\ 3 Department of Biomedicine, Faculty of Medicine, University of Porto, 4200-319 Porto, Portugal \\ 4 Department of Public Health and Forensic Sciences, and Medical Education, Faculty of Medicine, \\ University of Porto, 4200-319 Porto, Portugal \\ * Correspondence: isaacbarroso@gmail.com; Tel.: +351-939364059
}

Citation: Barroso, I.; Guimarães, J.T.; Severo, M.; Craveiro, V.; Ramos, E. Immunological Trajectories of White Blood Cells from Adolescence to Adulthood: Description and Determinants. Diagnostics 2021, 11, 2063. https://doi.org/10.3390/ diagnostics11112063

Academic Editor: Eric Deconinck

Received: 4 October 2021

Accepted: 5 November 2021

Published: 8 November 2021

Publisher's Note: MDPI stays neutral with regard to jurisdictional claims in published maps and institutional affiliations.

Copyright: (c) 2021 by the authors. Licensee MDPI, Basel, Switzerland. This article is an open access article distributed under the terms and conditions of the Creative Commons Attribution (CC BY) license (https:// creativecommons.org/licenses/by/ $4.0 /)$.

\begin{abstract}
Background: The immune system gradually matures early in life in the face of internal and external stimuli. Whether the immune responses are lasting and stable during the course of life is still unclear. Methods: As part of the EPITeen cohort, 1183 adolescents were prospectively evaluated at the ages of 13,17, 21, 24 and 27. Sociodemographic, behavioral and clinical data were collected by self- and face-to-face-administered questionnaires, along with a physical examination comprising anthropometric measurements and blood sample collections. Mixed-effects models were used to identify individual trajectories of white blood cells (WBC) and finite Gaussian mixture models were used to identify the clusters of individual trajectories. Results: Participants were allocated into six clusters based on the individual trajectories of WBC distribution. Higher Inflammatory Activation Cluster (11.4\%) had the highest total WBC count and neutrophils percentage, as well as the lowest percentage of lymphocytes. These participants had significantly higher odds of being overweight [OR $=2.44,95 \% \mathrm{CI}: 1.51-3.92]$. Lowest Levels of WBC Cluster (24.1\%) had the lowest total WBC count, being characterized by a higher participation on sports [OR $=1.54,95 \% \mathrm{CI}: 1.12-2.13$ ] Highest Proportion of Eosinophils Cluster (20.1\%) had the highest eosinophils percentage and the highest likelihood of having been diagnosed with a chronic disease [OR $=2.11,95 \% \mathrm{CI}: 1.43-3.13]$, namely "asthma or allergies" [OR $=14.0(1.73,112.2]$. Lowest Proportion of Eosinophils Cluster (29.1\%) had the lowest percentage of eosinophils and basophils, as well as the highest lymphocyte proportion. Participants in the Undefined Cluster (13.8\%) showed the highest percentage of monocytes and basophils and were also characterized by significant lower odds of having parents with 7-9 years of schooling [OR $=0.56,(0.32,0.99]$. Conclusions: In this study we identified distinct immunological trajectories of WBC from adolescence to adulthood that were associated with social, clinical and behavioral determinants. These results suggest that these immunological trajectories are defined early in life, being dependent on the exposures.
\end{abstract}

Keywords: immune response; white blood cells; cohort study; adolescence; adulthood

\section{Introduction}

The immune system gradually matures during childhood to adolescence [1,2]. Being a complex sensory and adaptative system it comprises a coordinated interplay of various cell populations, providing a balanced response for internal and external stimuli [3-5]. These stimuli trigger the development of immune responses early in life in the maturing immune system $[1,2,6]$. Whether these immune responses are lasting and stable during the course of life is still unclear. The literature is relatively scarce on how the individual's immune response is influenced by these external factors, namely whether this response is adaptive to stimulus (producing high levels of intraindividual variation) or if there are 
distinct immune-response patterns, which are relatively stable over time (low levels of intraindividual variation) [4,7-10]. Among the external stimuli, social and environmental determinants of health, which include socioeconomic, demographic, environmental determinants, along with the health system, may play an important role in modulating the immune system $[4,8,11-14]$. These determinants may influence and shape an individual's immune-cell population frequencies, defined as the individual 's 'immunotype', and predict a diverse set of functional responses [9,15-17]. On the other hand, recent evidence suggests that white blood cells (WBC) act in a coordinated fashion and their balance along with their subpopulations influences the function of immune system as a whole $[9,18]$. Since WBC are reliable markers of the immune response and their relative distribution affects the immune system globally, some epidemiological studies have assessed the relative frequency of WBC subpopulations in healthy individuals, however, studies that assess these immune cells responsiveness over a long time period are scarce $[8,18-20]$. Therefore, herein, we sought to assess whether distinct immunological trajectories of WBC develop in a stable manner over a long time period, from adolescence to adulthood, predicting functional responses. Additionally, we also intended to assess determinants of health that condition the development of the immunological response. For that purpose, we prospectively assessed total and differential WBC in a young, healthy population from adolescence to adulthood.

\section{Material and Methods}

Participants were adolescents from the Epidemiological Health Investigation of Teenagers in Porto (EPITeen). As already reported elsewhere [21], the population-based EPITeen cohort recruited adolescents born in 1990, who were enrolled at public and private schools in Porto, Portugal. These participants were evaluated at the ages of 13 (2003-2004), 17 (2007-2008), 21 (2011-2013), 24 (2014-2015) and 27 years (2017-2018).

\subsection{Data Collection}

In the first and second study waves, participants were evaluated at schools, and in the subsequent evaluations, they were invited to come to our University Department. Data collection was based on self-administered and face-to-face-questionnaires answered by the participants and by their parents. A physical examination comprising anthropometric measurements and the collection of a blood sample was performed. All procedures were standardized throughout time and performed by a team of trained health professionals.

\subsection{Blood Measurements}

A venous blood sample was drawn after an $8 \mathrm{~h}$ overnight fast. All the samples were analyzed at the central laboratory of the São João University Hospital Centre. Total and differential white blood cells (WBC) - neutrophils, monocytes, lymphocytes, eosinophils and basophils-were obtained using an automated blood counter Sysmex ${ }^{\circledR}$ XE-5000 (Sysmex Corp., Kobe, Japan). Serum high-sensitivity C-Reactive Protein (hs-CRP) was determined through particle-enhanced immunonephelometry using an autoanalyzer Dade Behring Nephelometer II ${ }^{\circledR}$ (Siemens AG, Munich, Germany).

\subsection{Covariates}

At 13 years old, adolescents' clinical information was obtained by asking to the parents and on the other waves information was reported by the participant. We evaluated the use of chronic medication in the previous 12 months and the presence of chronic disease was assessed asking if they had a disease requiring regular medical care (yes/no). Additionally, specified questions were asked about previous diagnoses of allergy and/or asthma and/or rhinitis separately for each of those three diseases. At 13 years this information was obtained from the parents. Data from 13- and 17-year-old participants was combined, and participants were classified as having a chronic disease if they reported a chronic disease in at least one of the evaluations. For this study, the variable allergic disease was 
created, corresponding to the diagnosis of at least one of these conditions: allergy, asthma, or rhinitis. For allergy, asthma, and rhinitis, the missing category included participants who did not know if they had the respective disease.

Parental education was based on the highest number of years they had successfully completed formal education, and participants were classified according to the parent with the highest level of education.

Practice of sports was a yes-or-no question considering the practice of sports in addition to the compulsory school curriculum, regardless of frequency or intensity. Data from the evaluation at 17 years was used when there were missing values for practice of sports at 13 years. Leisure-time physical activity was evaluated according to a closed four-choice question of increasing intensity categories: mainly sitting, mainly standing, active or very active [22].

Weight and height were obtained with the subject in light indoor clothes and no shoes. Weight was measured in kilograms, to the decimal, using a digital scale Tanita TBF-300 (Tanita Corp., Tokyo, Japan), and height was measured in centimeters, to the decimal, using a stadiometer 213I (Seca GmbH, Hamburg, Germany). Body mass index (BMI) at 13 years was calculated as weight (kilograms) divided by squared height (meters) and was standardized according to the sex- and age-specific-growth reference data for ages 5-19 years, from the world health organization (WHO) [23]. Participants were described as underweight if the $\mathrm{z}$-score $\mathrm{BMI}<-2$, normal weight if the $\mathrm{z}$-score $\mathrm{BMI} \geq-2 \& \leq+1$, overweight if the $\mathrm{z}$-score $\mathrm{BMI}>+1 \& \leq+2$, and obese if the $\mathrm{z}$-score BMI $>+2$. For BMI, the missing values at 13 years were maintained.

\subsection{Subjects}

At the first recruitment (2003-2004), 2786 eligible participants were identified and 2159 agreed to participate, resulting in an overall participation rate of $77.5 \%$. In the second wave, $1716(79.5 \%)$ of the baseline participants were re-evaluated at 17 years and 783 new participants were integrated in the cohort since they moved to the schools of Porto. From the entire cohort, 1764, 1094 and 1244 participants were re-evaluated at 21, 24 and at 27 years, respectively. WBC measurements from evaluations with concentrations of $h s-C R P \geq 10 \mathrm{mg} / \mathrm{L}$ were excluded from the analysis, since it constitutes a marker of acute infection [24]. In the present work, we included participants with valid WBC measurements in at least 3 of the 5 evaluations. Thus, our final sample was composed of 1183 subjects. Included participants had higher proportions of chronic medication, parental education and individuals practicing sports, however, reported being less active during leisure-time; additionally, among those included, the proportion of obese participants was lower than the nonincluded participants (Table 1 ).

Table 1. Comparison of baseline characteristics between included and nonincluded participants.

\begin{tabular}{|c|c|c|c|c|c|}
\hline \multirow[b]{2}{*}{ Characteristics } & \multicolumn{2}{|c|}{ Nonincluded } & \multicolumn{2}{|c|}{ Included } & \multirow[t]{2}{*}{$p$-Value } \\
\hline & $n$ & $\%$ & $n$ & $\%$ & \\
\hline & 1776 & 60.4 & 1166 & 39.6 & \\
\hline Sex & & & & & 0.407 \\
\hline Female & 921 & 51.9 & 586 & 50.3 & \\
\hline Chronic disease & & & & & 0.308 \\
\hline Yes & 206 & 19.0 & 187 & 20.9 & \\
\hline Missing & 690 & & 271 & & \\
\hline Allergic disease & & & & & 0.591 \\
\hline Yes & 341 & 33.1 & 295 & 34.3 & \\
\hline Missing/Did not know & 745 & & 306 & & \\
\hline Allergy & & & & & 0.496 \\
\hline Yes & 265 & 25.7 & 234 & 27.2 & \\
\hline
\end{tabular}


Table 1. Cont.

\begin{tabular}{|c|c|c|c|c|c|}
\hline \multirow[b]{2}{*}{ Characteristics } & \multicolumn{2}{|c|}{ Nonincluded } & \multicolumn{2}{|c|}{ Included } & \multirow[t]{2}{*}{$p$-Value } \\
\hline & $n$ & $\%$ & $n$ & $\%$ & \\
\hline Missing/Did not know & 746 & & 306 & & \\
\hline Asthma & & & & & 0.720 \\
\hline Yes & 118 & 11.5 & 104 & 12.1 & \\
\hline Missing/Did not know & 749 & & 303 & & \\
\hline Rhinitis & & & & & 0.313 \\
\hline Yes & 94 & 9.3 & 92 & 10.8 & \\
\hline Missing/Did not know & 768 & & 315 & & \\
\hline Chronic medication & & & & & 0.001 \\
\hline Yes & 522 & 51.8 & 516 & 59.4 & \\
\hline Missing & 768 & & 297 & & \\
\hline Parental education & & & & & $<0.001$ \\
\hline$\leq 6$ years & 553 & 31.3 & 221 & 19.0 & \\
\hline 7-9 years & 364 & 20.5 & 199 & 17.1 & \\
\hline 10-12 years & 399 & 22.5 & 332 & 28.5 & \\
\hline$>12$ years & 350 & 21.0 & 411 & 35.3 & \\
\hline Missing & 110 & & 3 & & \\
\hline Practice of sports & & & & & $<0.001$ \\
\hline Yes & 440 & 44.9 & 481 & 55.7 & \\
\hline Missing & 797 & & 302 & & \\
\hline Leisure-time physical activity & & & & & $<0.001$ \\
\hline Mainly sitting & 242 & 25.4 & 267 & 32.5 & \\
\hline Mainly standing & 227 & 23.8 & 168 & 20.5 & \\
\hline Active & 255 & 26.8 & 275 & 33.5 & \\
\hline Very active & 229 & 24.0 & 111 & 13.5 & \\
\hline Missing & 823 & & 345 & & \\
\hline Body mass index & & & & & 0.025 \\
\hline Underweight & 19 & 1.7 & 9 & 1.0 & \\
\hline Normal weight & 783 & 69.3 & 641 & 70.7 & \\
\hline Preobesity & 212 & 18.8 & 193 & 21.3 & \\
\hline Obesity & 116 & 10.3 & 64 & 7.1 & \\
\hline Missing & 646 & & 259 & & \\
\hline
\end{tabular}

\subsection{Statistical Analysis}

To identify the (individual) trajectories for total and differential WBC, we started by testing if the variables (total WBC and each of the subtypes) had a linear, quadratic or cubic trend with time; we found that, except basophiles which were linear, the others were quadratic. Then, to extract the individual trajectories in time for each variable, several parametrizations of mixed-effects models [25] were tested by including step-bystep random intercept, slope, and quadratic terms. We used finite Gaussian mixture models [26] to identify the clusters of individual trajectories with the same characteristics within clusters, and different characteristics between clusters. We used the random effects extracted in the previous step from the final mixed model as variables in mixture models. Finally, the number of clusters was chosen according to the Bayesian Information Criterion (BIC), assuming the lower the BIC, the better the solution was.

To visualize the expected value for the trajectories of each differential and total WBC, a mixed-effect model with linear and quadratic terms was fitted.

A chi-squared test was used to compare proportions. Associations between the clusters identified and the subjects' characteristics at 13 years were estimated using odds ratio (OR) and $95 \%$ confidence intervals (95\% CI) calculated by multinomial logistic regression. The final models were adjusted for sex and parental education.

Statistical significance was considered with a significance level of 0.05 . The packages nlme and mclust from the R software v.3.6.0 were used to estimate the mixed-effects models and the finite Gaussian mixture models, respectively [27]. Other statistical analysis was performed using IBM ${ }^{\circledR}$ SPSS $^{\circledR}$ Statistics version 25.0 (IBM Corp., Armonk, NY, USA). 


\subsection{Ethical Considerations}

The study complies with the Declaration of Helsinki and was approved by the National Commission of Data Protection and by the Ethics Committee from the São João University Hospital Centre and from the Institute of Public Health of the University of Porto. Procedures to guarantee data confidentiality and protection were assured. Parents and adolescents received written and oral information explaining the purpose and the design of the study, and written informed consent was obtained from both when the participants were minors. For waves when they were at least 18 years of age, the consent was only obtained from the participants.

\section{Results}

Participants were allocated into six clusters based on the individual leukocyte distribution trajectories of the 1183 participants who fulfilled the inclusion criteria. The probability of belonging to the most likely cluster ranged from 0.79 to 0.98 , showing a good cluster' identification.

One of the clusters was composed of only 17 participants and was not considered for further analyses since they were considered probable outliers due to extreme values in at least one of the evaluations. Thus, our final analysis included 1166 participants. The clusters were named according to a distinctive characteristic, except for one that was named as undefined: Higher Inflammatory Activation Cluster (Cluster HIA); Lowest Levels of WBC Cluster (Cluster LLWBC); Highest Proportion of Eosinophils Cluster (Cluster HPEo); Lowest Proportion of Eosinophils Cluster (Cluster LPEo); Undefined Cluster (Cluster Un). Figure 1 describes total and differential WBC according to the identified clusters (Tables A1 and A2). Overall, subjects in Cluster HIA $(n=136)$ had the highest total WBC count and percentage of neutrophils, as well as the lowest percentage of lymphocytes, while participants in Cluster LLWBC $(n=285)$ had the lowest total WBC count without significant differences regarding the distribution of the differential WBC. The participants in the Cluster HPEo $(n=238)$ showed the highest eosinophils proportion and lowest percentage of neutrophils, while those in Cluster LPEo $(n=344)$ had the lowest percentage of eosinophils, basophils and monocytes, as well as the highest lymphocyte proportion. Participants in Cluster Un $(n=163)$ showed the highest percentage of monocytes and basophils.
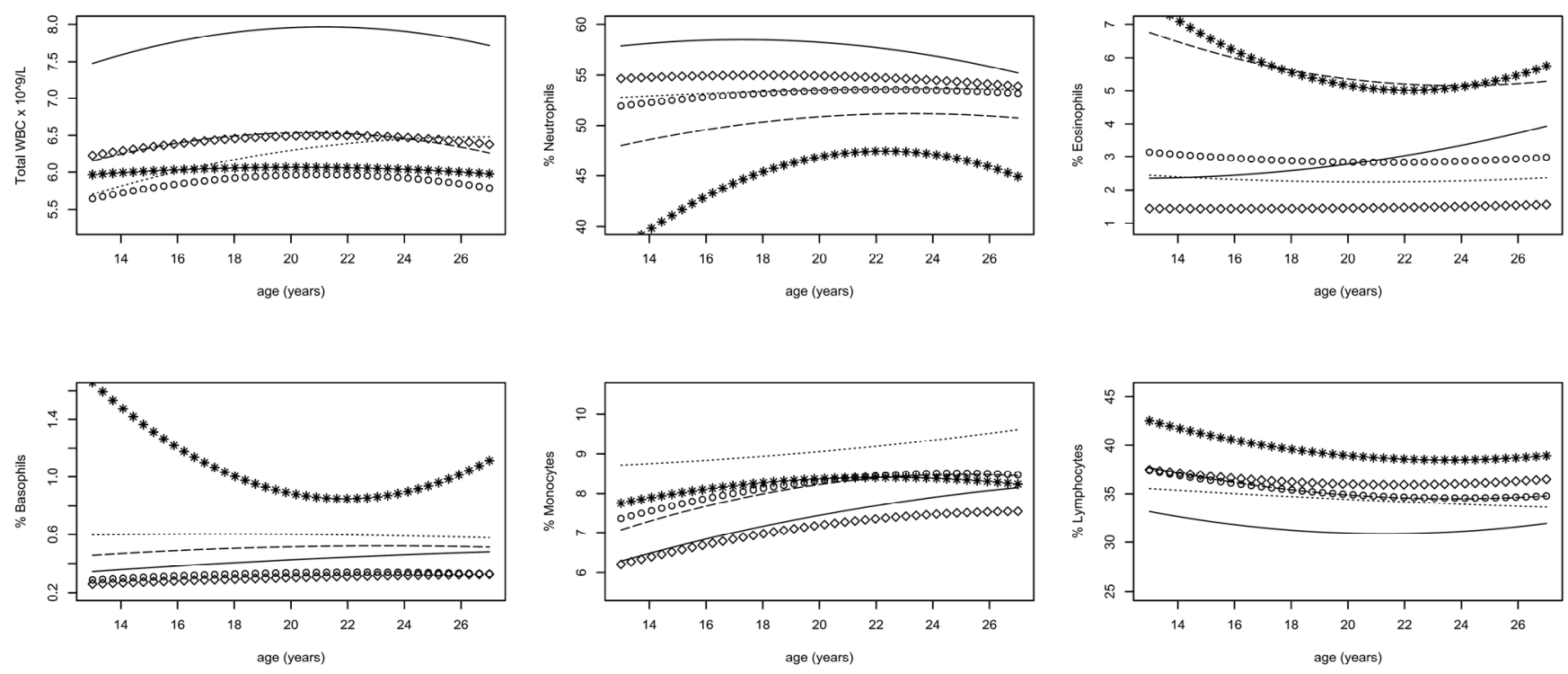

Legend: Cluster HIA: Higher Inflammatory Activation Cluster [-]; Cluster LLWBC: Lowest Levels of WBC Cluster [o] ; Cluster HPEo: Highest Proportion of Eosinophils Cluster [- -]; Cluster LPEo: Lowest Proportion of Eosinophils Cluster [ $\diamond]$; Cluster Un: Undefined Cluster […..]; Outlier Cluster [*].

Figure 1. Clusters according to total and differential white blood cells (WBC) trajectories. 
Clusters according to sociodemographic and health characteristics are drawn in Table 2. Cluster HIA showed a significantly higher percentage of individuals with preobesity and obesity. Cluster LLWBC had a significantly higher percentage of individuals practicing sports and higher percentage of participants reporting being very active in leisure-time physical activity. Cluster HPEo showed a significantly higher percentage of individuals with chronic disease, allergy, asthma and rhinitis. Cluster LPEo had the highest percentage of females and fewer individuals who reported allergic disease. Cluster Un had a higher percentage of participants with highest parental education, though without statistical significance.

Table 2. Comparison of demographic and behavioral characteristics by clusters.

\begin{tabular}{|c|c|c|c|c|c|c|}
\hline & $\begin{array}{c}\text { Cluster HIA } \\
\text { N (\%) }\end{array}$ & $\begin{array}{c}\text { Cluster } \\
\text { LLWBC } \\
\text { N (\%) }\end{array}$ & $\begin{array}{c}\text { Cluster HPEo } \\
\text { N (\%) }\end{array}$ & $\begin{array}{c}\text { Cluster LPEo } \\
\text { N (\%) }\end{array}$ & $\begin{array}{c}\text { Cluster Un } \\
\text { N (\%) }\end{array}$ & $p$-Value \\
\hline Characteristics & $136(11.7)$ & $285(24.4)$ & $238(20.4)$ & $344(29.5)$ & $163(14.0)$ & \\
\hline Sex & & & & & & $<0.001$ \\
\hline Female & $68(50.0)$ & $104(36.5) *$ & $94(39.5) *$ & $231(67.2) *$ & $89(54.6)$ & \\
\hline Male & $68(50.0)$ & $181(63.5)$ * & $144(60.5)$ * & $113(32.8)$ * & $74(45.4)$ & \\
\hline Chronic disease & & & & & & $<0.001$ \\
\hline No & $110(82.1)$ & $230(36.5)$ & $164(68.9)$ * & $281(82.4)$ & $135(83.3)$ & \\
\hline Yes & $24(17.9)$ & $49(63.5)$ & $74(31.0) *$ & $60(17.5)$ & $27(16.7)$ & \\
\hline Allergic disease & & & & & & $<0.001$ \\
\hline No & $94(70.1)$ & $190(69.1)$ & $113(47.7) *$ & $255(76.1) *$ & $110(69.2)$ & \\
\hline Yes & $40(29.9)$ & $85(30.9)$ & $124(52.3)$ * & $80(23.9) *$ & $49(30.8)$ & \\
\hline Allergy & & & & & & $<0.001$ \\
\hline No & $100(74.1)$ & $206(74.9)$ & $136(57.4) *$ & $276(82.1) *$ & $124(78.0)$ & \\
\hline Yes & $35(25.9)$ & $69(25.1)$ & $101(42.6)$ * & $60(17.9) *$ & $35(22.0)$ & \\
\hline Asthma & & & & & & $<0.001$ \\
\hline No & $121(91.0)$ & $249(89.6)$ & $170(72.6)$ * & $312(93.4) *$ & $146(91.8)$ & \\
\hline Yes & $12(9.0)$ & $29(10.4)$ & $64(27.4) *$ & $22(6.6) *$ & $13(8.2)$ & \\
\hline Rhinitis & & & & & & $<0.001$ \\
\hline No & 125 (92.6) & $248(89.5)$ & $197(83.8)$ * & $317(93.8)$ & $151(95.5)$ & \\
\hline Yes & $10(7.4)$ & $29(10.5)$ & $38(16.2) *$ & $21(6.2)$ & $8(5.0)$ & \\
\hline Chronic medication & & & & & & 0.737 \\
\hline No & $42(40.8)$ & $80(40.2)$ & $71(36.8)$ & $107(42.3)$ & $53(43.8)$ & \\
\hline Yes & $61(59.2)$ & $119(59.8)$ & $122(63.2)$ & $146(57.7)$ & $68(56.2)$ & \\
\hline Parental education & & & & & & 0.201 \\
\hline$\leq 6$ years & $33(24.3)$ & $45(15.8)$ & $37(15.5)$ & $69(20.1)$ & $37(22.8)$ & \\
\hline 7-9 years & $20(14.7)$ & $45(15.8)$ & $40(16.8)$ & $71(20.7)$ & $23(14.2)$ & \\
\hline 10-12 years & $37(27.2)$ & $92(32.4)$ & $71(29.8)$ & $93(27.1)$ & $39(24.1)$ & \\
\hline$\geq 12$ years & $46(33.8)$ & $102(35.9)$ & $90(37.8)$ & $110(32.1)$ & $63(38.9)$ & \\
\hline Practice of sports & & & & & & 0.044 \\
\hline No & $61(45.5)$ & $104(37.0)$ & $92(38.9)$ & $161(47.5)$ & $75(46.6)$ & \\
\hline Yes & $73(54.5)$ & $177(63.0)$ & $145(61.2)$ & $178(52.5)$ & $86(53.4)$ & \\
\hline Leisure-time physical activity & & & & & & 0.098 \\
\hline Mainly sitting & $39(29.5)$ & $72(26.3)$ & $54(23.1)$ & $112(33.3)$ & $50(31.8)$ & \\
\hline Mainly standing & $24(18.2)$ & $64(23.4)$ & $51(21.8)$ & $73(21.7)$ & $36(22.9)$ & \\
\hline Active & $53(40.2)$ & $84(30.7)$ & $93(39.7)$ & $107(31.8)$ & $47(29.9)$ & \\
\hline Very active & $16(12.1)$ & $54(19.7)$ & $36(15.4)$ & $44(13.1)$ & $24(15.3)$ & \\
\hline Body mass index & & & & & & 0.007 \\
\hline Underweight & $0(0.0)$ & $3(1.4)$ & $5(2.5)$ & $1(0.4)$ & $0(0.0)$ & \\
\hline Normal weight & $62(56.9) *$ & $145(69.7)$ & $142(70.6)$ & $195(75.9)$ & $97(73.5)$ & \\
\hline Preobesity & $33(30.3)$ & $50(24.0)$ & $39(19.4)$ & $43(16.7)$ & $28(21.2)$ & \\
\hline Obesity & $14(12.8)$ & $10(4.8)$ & $15(7.5)$ & $18(7.0)$ & $7(5.3)$ & \\
\hline hs-CRP (median) & & & & & & 0.503 \\
\hline$<0.30 \mathrm{mg} / \mathrm{L}$ & $39(42.9)$ & $78(47.3)$ & $76(43.7)$ & $107(51.2)$ & $55(50.5)$ & \\
\hline$\geq 0.30 \mathrm{mg} / \mathrm{L}$ & $52(57.1)$ & 87 (52.7) & $98(56.3)$ & $102(48.8)$ & $54(49.5)$ & \\
\hline \multirow[t]{3}{*}{ hs-CRP (mg/L) } & Median & Median & Median & Median & Median & 0.545 \\
\hline & (25th-75th) & (25th-75th) & (25th-75th) & (25th-75th) & (25th-75th) & \\
\hline & $0.30(0.20-1.10)$ & $0.30(0.00-0.70)$ & $0.30(0.20-0.60)$ & $\begin{array}{c}0.20 \\
(0.10-0.80)\end{array}$ & $\begin{array}{c}0.20 \\
(0.00-0.70)\end{array}$ & \\
\hline
\end{tabular}

Legend: hs-CRP: high-sensitivity C-reactive protein. hs-CRP median = $0.30 \mathrm{mg} / \mathrm{L}$; Cluster HIA: Higher Inflammatory Activation Cluster; Cluster LLWBC: Lowest Levels of WBC Cluster; Cluster HPEo: Highest Proportion of Eosinophils Cluster; Cluster LPEo: Lowest Proportion of Eosinophils Cluster; Cluster Un: Undefined Cluster; $p$-values $<0.05$ are in bold. * post hoc analysis based on residuals of Pearson's chi-squared test with Bonferroni correction $(p<0.05)$. 
The results of the crude and adjusted multinomial logistic regression are depicted in Table 3. Female participants had significantly lower odds of being in any cluster. In the crude model, the subjects in Cluster HIA had significantly higher odds of being overweight [OR $=2.44,95 \%$ CI:1.51-3.92]. Participants in Cluster LLWBC and Cluster HPEo showed significantly higher odds of practicing sports, [OR $=1.54,95 \% \mathrm{CI}: 1.12-2.13$ and $\mathrm{OR}=1.43$, 95\%CI:1.02-2.00, respectively]. Moreover, participants in Cluster HPEo also showed significantly higher odds of having chronic disease [OR $=2.11,95 \% \mathrm{CI}: 1.43-3.13]$ or allergic disease [OR $=14.0,95 \% \mathrm{CI}: 1.73-112.2]$. Participants in Cluster Un had significantly lower odds of having parents with 7-9 years of schooling [OR $=0.56,95 \% \mathrm{CI}: 0.32-0.99$ ]. After the adjustment for sex and parental education, participants in Cluster HIA had significantly higher odds of being overweight [OR $=2.38,95 \% \mathrm{CI}: 1.47-3.86]$. Subjects in Cluster HPEo showed significantly higher odds of having chronic disease [OR $=2.08$, 95\%CI:1.39-3.10], and allergic disease [OR $=3.54,95 \% \mathrm{CI}: 2.45-5.10]$.

Table 3. Evaluation of social, clinical and behavioral determinants of the clusters.

\begin{tabular}{|c|c|c|c|c|c|c|c|c|}
\hline \multirow[b]{2}{*}{ Characteristics } & \multicolumn{4}{|c|}{ Crude OR $(95 \% \mathrm{CI})$} & \multicolumn{4}{|c|}{ Adjusted * OR (95\% CI) } \\
\hline & $\begin{array}{l}\text { Cluster } \\
\text { HIA }\end{array}$ & $\begin{array}{l}\text { Cluster } \\
\text { LLWBC }\end{array}$ & $\begin{array}{l}\text { Cluster } \\
\text { HPEo }\end{array}$ & $\begin{array}{l}\text { Cluster } \\
\text { Un }\end{array}$ & $\begin{array}{l}\text { Cluster } \\
\text { HIA }\end{array}$ & $\begin{array}{l}\text { Cluster } \\
\text { LLWBC }\end{array}$ & $\begin{array}{l}\text { Cluster } \\
\text { HPEo }\end{array}$ & $\begin{array}{l}\text { Cluster } \\
\text { Un }\end{array}$ \\
\hline \multicolumn{9}{|l|}{ Sex } \\
\hline Female & $\begin{array}{l}0.49(0.22 \\
0.73)\end{array}$ & $\begin{array}{l}0.28(0.20 \\
0.39)\end{array}$ & $\begin{array}{l}0.32(0.23 \\
0.45)\end{array}$ & $\begin{array}{l}0.59(0.40 \\
0.86)\end{array}$ & $\begin{array}{l}0.49(0.32 \\
0.73)\end{array}$ & $\begin{array}{l}0.28(0.20 \\
0.40)\end{array}$ & $\begin{array}{l}0.32(0.23 \\
0.46)\end{array}$ & $\begin{array}{l}0.59(0.40, \\
0.87)\end{array}$ \\
\hline Male & 1.00 & 1.00 & 1.00 & 1.00 & 1.00 & 1.00 & 1.00 & 1.00 \\
\hline \multicolumn{9}{|l|}{ Parental education } \\
\hline$\leq 6$ years & $\begin{array}{c}1.15(0.67 \\
1.98)\end{array}$ & $\begin{array}{l}0.70(0.44 \\
1.12)\end{array}$ & $\begin{array}{c}0.66(0.41 \\
1.08)\end{array}$ & $\begin{array}{c}0.93(0.53 \\
1.54)\end{array}$ & $\begin{array}{c}1.21(0.70 \\
2.08)\end{array}$ & $\begin{array}{l}0.76(0.47 \\
1.22)\end{array}$ & $\begin{array}{l}0.71(0.43 \\
1.17)\end{array}$ & $\begin{array}{c}0.96(0.58, \\
1.59)\end{array}$ \\
\hline $7-9$ years & $\begin{array}{c}0.68(0.37 \\
1.24)\end{array}$ & $\begin{array}{c}0.68(0.43 \\
1.08)\end{array}$ & $\begin{array}{l}0.70(0.43 \\
1.12)\end{array}$ & $\begin{array}{l}0.56(0.32 \\
0.99)\end{array}$ & $\begin{array}{c}0.69(0.38 \\
1.27)\end{array}$ & $\begin{array}{l}0.71(0.44 \\
1.14)\end{array}$ & $\begin{array}{l}0.72(0.44 \\
1.17)\end{array}$ & $\begin{array}{c}0.57(0.33 \\
1.00)\end{array}$ \\
\hline 10-12 years & $\begin{array}{l}0.96(0.58 \\
1.60)\end{array}$ & $\begin{array}{c}1.07(0.72 \\
1.58)\end{array}$ & $\begin{array}{l}0.94(0.62 \\
1.43)\end{array}$ & $\begin{array}{l}0.73(0.45 \\
1.18)\end{array}$ & $\begin{array}{l}0.97(0.58 \\
1.63)\end{array}$ & $\begin{array}{c}1.09(0.73 \\
1.63)\end{array}$ & $\begin{array}{c}0.96(0.63 \\
1.46)\end{array}$ & $\begin{array}{l}0.73(0.45 \\
1.19)\end{array}$ \\
\hline$\geq 12$ years & 1.00 & 1.00 & 1.00 & 1.00 & 1.00 & 1.00 & 1.00 & 1.00 \\
\hline \multicolumn{9}{|l|}{ Chronic disease } \\
\hline No & 1.00 & 1.00 & 1.00 & 1.00 & 1.00 & 1.00 & 1.00 & 1.00 \\
\hline Yes & $\begin{array}{c}1.02(0.61 \\
1.72)\end{array}$ & $\begin{array}{c}1.00(0.66 \\
1.51)\end{array}$ & $\begin{array}{l}2.11(1.43, \\
3.13)\end{array}$ & $\begin{array}{c}0.94(0.57 \\
1.54)\end{array}$ & $\begin{array}{c}1.03(0.61 \\
1.75)\end{array}$ & $\begin{array}{c}0.97(0.64 \\
1.49)\end{array}$ & $\begin{array}{c}2.08(1.39 \\
3.10)\end{array}$ & $\begin{array}{c}0.95(0.58 \\
1.57)\end{array}$ \\
\hline \multicolumn{9}{|l|}{ Allergic disease } \\
\hline No & 1.00 & 1.00 & 1.00 & 1.00 & 1.00 & 1.00 & 1.00 & 1.00 \\
\hline Yes & $\begin{array}{c}2.25(0.46 \\
10.9)\end{array}$ & $\begin{array}{c}0.96(0.37 \\
2.48)\end{array}$ & $\begin{array}{c}14.0(1.73 \\
112.2)\end{array}$ & $\begin{array}{c}1.38(0.40 \\
4.72)\end{array}$ & $\begin{array}{c}1.37(0.87 \\
2.15)\end{array}$ & $\begin{array}{c}1.44(0.99 \\
2.08)\end{array}$ & $\begin{array}{c}3.54(2.45 \\
5.10)\end{array}$ & $\begin{array}{c}1.45(0.95 \\
2.21)\end{array}$ \\
\hline \multicolumn{9}{|l|}{ BMI } \\
\hline $\begin{array}{l}\text { Underweight and normal } \\
\text { weight }\end{array}$ & 1.00 & 1.00 & 1.00 & 1.00 & 1.00 & 1.00 & 1.00 & 1.00 \\
\hline Preobesity and obesity & $\begin{array}{c}2.44(1.51 \\
3.92)\end{array}$ & $\begin{array}{c}1.30(0.86 \\
1.97)\end{array}$ & $\begin{array}{c}1.18(0.77 \\
1.80)\end{array}$ & $\begin{array}{c}1.16(0.72 \\
1.88)\end{array}$ & $\begin{array}{c}2.38(1.47 \\
3.86)\end{array}$ & $\begin{array}{c}1.21(0.79 \\
1.86)\end{array}$ & $\begin{array}{c}1.10(0.71 \\
1.71)\end{array}$ & $\begin{array}{c}1.15(0.71, \\
1.87)\end{array}$ \\
\hline \multicolumn{9}{|l|}{ Sports practice } \\
\hline No & 1.00 & 1.00 & 1.00 & 1.00 & 1.00 & 1.00 & 1.00 & 1.00 \\
\hline Yes & $\begin{array}{c}1.08(0.73 \\
1.62)\end{array}$ & $\begin{array}{l}1.54(1.12, \\
2.13)\end{array}$ & $\begin{array}{l}1.43(1.02, \\
2.00)\end{array}$ & $\begin{array}{c}1.04(0.71 \\
1.51)\end{array}$ & $\begin{array}{l}0.97(0.64 \\
1.48)\end{array}$ & $\begin{array}{c}1.20(0.85 \\
1.69)\end{array}$ & $\begin{array}{c}1.12(0.79 \\
1.61)\end{array}$ & $\begin{array}{c}0.92(0.62 \\
1.36)\end{array}$ \\
\hline
\end{tabular}

Legend: BMI: body mass index; CI: confidence interval; OR: odds ratio; Bold values represent statistically significant results; Cluster HIA: Higher Inflammatory Activation Cluster; Cluster LLWBC: Lowest Levels of WBC Cluster; Cluster HPEo: Highest Proportion of Eosinophils Cluster; Cluster Un: Undefined Cluster; * adjusted for sex and parental education.

\section{Discussion}

In this study, we were able to identify distinct WBC trajectories from adolescence to adulthood. To the best of our knowledge, this is the first study to prospectively assess these 
immune cells, identifying different subpopulations of healthy individuals with distinct immunological trajectories of WBC, assessed from 13 to 27 years of age.

The consistency of the relative proportion of each subpopulation suggests that there is an immune-response pattern defined in the first years of life, or even in the prenatal period, that is relatively stable over the years. Since the different leukocyte populations operate in a tightly coordinated fashion with direct interactions with several other immune mediators, their relative distribution influences the immune-system function as a whole [9]. These results corroborate previous studies which have found that despite the considerable interindividual variation in the frequency of leukocytes subsets, the immune profile of each individual is remarkably stable $[7,8,28]$. However, unlike these studies in which the evaluation period did not exceed several months, this study carried out a longitudinal analysis over a 14-year period, in healthy individuals.

The results regarding the association between the trajectories and the characteristics of the participants, give us a potential explanation for these clusters supporting the causal relationship. The Higher Inflammatory Activation Cluster was associated with a higher pattern of immunological activation, though within normal range, with the highest levels of total WBC and percentage of neutrophils as well as the lowest percentage of lymphocytes. Participants included in this cluster also have higher odds of being overweight and obese, even after adjustment for sex and parental education, a proxy of the socioeconomic status. The underlying mechanism linking weight gain with an increase in total WBC levels is not fully understood, however the potential proinflammatory effect of adipose tissue is well known. The high levels of circulating leukocytes in the obese phenotype may reflect the response to stimulation of the inflammatory mediators produced by adipocytes [29-31]. In addition, this proinflammatory environment promotes increased levels of neutrophils which, in turn, secrete several proinflammatory mediators, contributing to the increase in systemic inflammation [32-35]. Leptin may also be involved since it stimulates myeloid differentiation, decreasing after weight loss [36,37]. On the other hand, the lymphocytes represent the regulatory arm of the immune system, are involved in the suppression of inflammation, and their levels are reduced with the increase in systemic inflammation [32,33].

The Lowest Levels of WBC Cluster was associated with an immunoprotective pattern of response, with the lowest total WBC levels but without significant differences regarding the proportion of each subpopulation. These results may be explained by the higher physical activity reported by the members of this cluster. Previous studies have shown that high levels of physical activity have been associated with reduced systemic inflammation and reduced total WBC levels in both men and women, regardless of the initial weight [38-41]. In fact, exercise may lower WBC count through its direct impact on bone marrow hematopoiesis in addition to reducing the trafficking of leukocytes between secondary lymphoid organs and blood [39,42].

The Highest Proportion of Eosinophils Cluster was characterized by the highest percentage of eosinophils and a high proportion of basophils, a characteristic allergic response pattern [43], which is in agreement with the clinical characteristics of the participants belonging to this cluster. In fact, in asthma and other allergic diseases the levels of the eosinophils and basophils are observed to be considerably increased [43]. After eosinophils' activation in the air tract due to pharmacological, hormonal, infectious, or environmental stimuli, a Th2-driven immune response is initiated, which causes airway hyper-responsiveness and chronic remodeling [43,44]. Moreover, eosinophils secrete cytokines, chemokines and cytotoxic proteins that contribute to the activation of macrophages along with the degranulation of mast cells and basophils, triggering the release of various allergic mediators, such as histamine and TNF- $\alpha[44,45]$. Therefore, the increase in basophils observed in asthma and other allergic diseases also promotes the progression in the allergic reactions, since these cells migrate from the blood compartment to inflamed tissues, acting as inflammatory mediators $[45,46]$. On the contrary, the Lowest Proportion of Eosinophils Cluster was characterized by the lowest percentage of eosinophils and basophils, having the lowest 
proportion of allergic disease. In this sense, individuals belonging to this cluster seem to have a contrasting immune-response pattern compared with those in Cluster HPEo.

Those who belong to the Undefined Cluster were characterized by the highest percentage of monocytes and basophils and a considerable increase in the total WBC levels. Since this cluster does not have distinctive characteristics, it probably aggregates all those that do not have a defined pattern.

Taken together, these results show that immunological trajectories of WBC are already developed in adolescence and are stable into adulthood. Furthermore, these results support recent evidence which suggests that extrinsic factors are major drivers of inter-individual variation in the immune system, despite the extent of these differences between healthy individuals being largely unknown $[3,4,7,47]$. This immune-system diversity generates multiple immunotypes, which are remarkable stable over time in individuals when compared to interindividual heterogeneity $[3,4]$. In this conception, the individual immune phenotype would constitute a "stability island" in which the immune parameters remain relatively stable. $[3,7,28]$. Therefore, it is conceivable that the exposures to which one is subjected would be crucial for the individual's immune-system development, promoting distinct immunological trajectories. Here, we add new insights upon the development and stability of the immunological trajectories of WBC in the long term.

This study should be interpreted in light of some limitations. We lost some participants over time, as some refused to give a blood sample. Included participants tend to have a healthier profile than excluded participants (presented a higher proportion of chronic medication, higher parental education, higher proportion of individuals practicing sports and lower proportion obese people). Although this selection bias may prevent knowledge of the prevalence of each cluster, it does not change its characteristics and the association with sociodemographic and clinical characteristics. Additionally, the bias may have an impact on hiding other potential clusters, since it contributes to creating a more homogenous sample than the population. Furthermore, the absence of leukocyte immunophenotyping does not allow the evaluation of specific WBC subsets, and therefore, hinders a deeper characterization of the studied population. On the other hand, the relatively large and apparently healthy sample is one of the strengths of this study, since most studies are conducted in small and nonhealthy samples. In addition, the 14 years of follow-up makes this study a unique opportunity to longitudinally understand a key period of life-the transition from adolescence to adulthood. In fact, the immune system gradually matures during infancy until adolescence, this life period being decisive in immune-system development, shaping the response patterns observed in adulthood [10,48]. Moreover, since at the age of 27 it is usually too early for the onset of chronic diseases, most participants had not undergone pharmacological therapy, which could have compromised the findings of the study. Therefore, our results allow us to infer causality and may be fairly helpful for stating future research hypotheses.

\section{Conclusions}

In this study were identified distinct, lasting and stable immunological trajectories of WBC from adolescence to adulthood. These results do suggest that these immunological trajectories are defined early in life and may determine and predict the functional responses observed in adulthood. Moreover, our results show that these immunological trajectories are conditioned by the stimuli in which the individual is exposed, leading to the modulation of the immune system, in order to adapt it to the external requirements. To the best of our knowledge this is the first study to longitudinally identify these patterns of immunological responses in a healthy population. A better understanding of these immunological trajectories developed in early life and the mechanisms by which external stimuli may influence and shape the immune repertoire should be crucial to help design new strategies that promote long-term immunological health. 
Author Contributions: I.B., Conceptualization, data curation, formal analysis, methodology, writingoriginal draft; J.T.G., supervision, review and editing; M.S., methodology, formal analysis; V.C., methodology, formal analysis; E.R., supervision, review and editing. All authors have read and agreed to the published version of the manuscript.

Funding: This study was funded by FEDER through the Operational Programme Competitiveness and Internationalization and by national funding from the Foundation for Science and TechnologyFCT (Portuguese Ministry of Science, Technology and Higher Education) (POCI-01-0145-FEDER016829), under Unidade de Investigação em Epidemiologia-Instituto de Saúde Pública da Universidade do Porto (EPIUnit) (POCI-01-0145-FEDER-006862; Ref. UID/DTP/04750/2013); and the individual PhD Grant to VC (PD/BD/149264/2019), co-funded by the FCT and the POPH/FSE Program.

Institutional Review Board Statement: The study was conducted according to the guidelines of the Declaration of Helsinki and approved by the Ethics Committee of the São João University Hospital Centre and the Ethics Committee of the Institute of Public Health from the University of Porto, and appropriate standard procedures were developed to guarantee data confidentiality and protection. Written and oral information explaining the purpose and design of the study was given to the adolescents and parents/legal guardians, as signed written informed consent was obtained from both at 13 and 17 years, and only from participants at 21, 24, and 27 years.

Informed Consent Statement: Procedures to guarantee data confidentiality and protection were assured. Parents and adolescents received written and oral information explaining the purpose and the design of the study, and written informed consent was obtained from both when the participants were minors; for waves when they were at least 18 years of age, the consent was only obtained from the participants.

Data Availability Statement: Data is contained within the article.

Conflicts of Interest: There are no conflicts of interest to declare.

\section{Appendix A}

Table A1. Description of the total and differential white blood cells (WBC) at 13, 17, 21, 24 and 27 years of age according to the clusters.

\begin{tabular}{|c|c|c|c|c|c|c|}
\hline & $\begin{array}{c}\text { Total } \\
n=1183\end{array}$ & $\begin{array}{c}\text { Cluster } H I A \\
n=163\end{array}$ & $\begin{array}{c}\text { Cluster } \\
L L W B C \\
n=136\end{array}$ & $\begin{array}{c}\text { Cluster HPEo } \\
n=285\end{array}$ & $\begin{array}{c}\text { Cluster LPEo } \\
n=344\end{array}$ & $\begin{array}{c}\text { Cluster } U n \\
n=238\end{array}$ \\
\hline Total $\mathrm{WBC}^{\mathrm{a}}$ & Mean (SD) & Mean (SD) & Mean (SD) & Mean (SD) & Mean (SD) & Mean (SD) \\
\hline 13 & $6.15(1.50)$ & $7.49(2.09)$ & $5.61(1.04)$ & $6.15(1.32)$ & $6.16(1.36)$ & $5.83(1.37)$ \\
\hline 17 & $6.35(1.51)$ & 7.58 (1.98) & $5.91(1.15)$ & $6.30(1.41)$ & $6.35(1.39)$ & $6.09(1.47)$ \\
\hline 21 & $6.56(1.71)$ & $8.08(2.00)$ & $5.98(1.17)$ & $6.60(1.60)$ & $6.56(1.74)$ & $6.33(1.65)$ \\
\hline 24 & $6.45(1.71)$ & $8.04(2.05)$ & $5.86(1.14)$ & $6.43(1.58)$ & $6.36(1.64)$ & $6.54(1.84)$ \\
\hline 27 & $6.35(1.56)$ & $7.55(1.88)$ & $5.79(0.94)$ & $6.25(1.28)$ & $6.44(1.69)$ & $6.43(1.80)$ \\
\hline Trend & B ( $p$-value) & B ( $p$-value) & B ( $p$-value) & B ( $p$-value) & B ( $p$-value) & B ( $p$-value) \\
\hline Age & $0.22(<0.001)$ & $0.31(0.043)$ & $0.21(<0.001)$ & $0.28(<0.001)$ & 0.17 (0.018) & $0.22(0.032)$ \\
\hline Age $^{2}$ & $-0.005(<0.001)$ & $-0.007(0.055)$ & $-0.005(<0.001)$ & $-0.007(<0.001)$ & $-0.003(0.025)$ & $-0.004(0.105)$ \\
\hline Neutrophils $b$ & Mean (SD) & Mean (SD) & Mean (SD) & Mean (SD) & Mean (SD) & Mean (SD) \\
\hline 13 & $52.3(10.5)$ & $57.9(9.00)$ & $51.8(9.00)$ & $47.9(8.62)$ & $54.5(9.97)$ & $53.4(10.8)$ \\
\hline 17 & $53.8(9.06)$ & $58.9(9.29)$ & $53.9(8.49)$ & $50.2(8.41)$ & $55.2(8.92)$ & $52.9(8.58)$ \\
\hline 21 & $53.7(8.80)$ & $58.5(7.36)$ & $53.0(7.33)$ & $50.7(8.62)$ & $54.7(9.29)$ & $53.3(9.29)$ \\
\hline 24 & $53.7(8.78)$ & $56.8(7.13)$ & $53.7(7.63)$ & $51.3(8.50)$ & $54.7(9.16)$ & $54.2(9.24)$ \\
\hline 27 & $52.9(8.16)$ & $55.4(7.13)$ & $53.0(6.44)$ & $50.8(7.24)$ & $53.8(9.33)$ & $53.2(8.85)$ \\
\hline Trend & $\mathrm{B}$ ( $p$-value) & B ( $p$-value) & B ( $p$-value) & B ( $p$-value $)$ & B ( $p$-value) & B ( $p$-value $)$ \\
\hline Age & $0.95(<0.001)$ & $1.19(0.062)$ & $0.82(0.494)$ & $1.41(0.002)$ & $0.48(0.257)$ & $0.33(0.580)$ \\
\hline Age $^{2}$ & $-0.023(<0.001)$ & $-0.034(0.031)$ & $-0.18(0.076)$ & $-0.030(0.007)$ & $-0.014(0.200)$ & $-0.007(0.645)$ \\
\hline
\end{tabular}


Table A1. Cont.

\begin{tabular}{|c|c|c|c|c|c|c|}
\hline & $\begin{array}{c}\text { Total } \\
n=1183\end{array}$ & $\begin{array}{c}\text { Cluster } H I A \\
n=163\end{array}$ & $\begin{array}{c}\text { Cluster } \\
L L W B C \\
n=136\end{array}$ & $\begin{array}{c}\text { Cluster HPEo } \\
n=285\end{array}$ & $\begin{array}{c}\text { Cluster LPEo } \\
n=344\end{array}$ & $\begin{array}{c}\text { Cluster Un } \\
n=238\end{array}$ \\
\hline Eosinophils $b$ & Mean (SD) & Mean (SD) & Mean (SD) & Mean (SD) & Mean (SD) & Mean (SD) \\
\hline 13 & $3.43(2.92)$ & $2.47(1.33)$ & $3.19(1.52)$ & $6.83(3.28)$ & $1.45(0.66)$ & $2.41(1.27)$ \\
\hline 17 & $2.81(2.13)$ & $2.30(1.22)$ & $2.77(1.39)$ & $5.45(2.34)$ & $1.44(0.74)$ & $2.28(1.13)$ \\
\hline 21 & $2.86(1.96)$ & $2.88(1.34)$ & $2.84(1.29)$ & $5.36(2.23)$ & $1.51(0.75)$ & $2.27(1.06)$ \\
\hline 24 & $3.07(2.22)$ & $3.58(1.96)$ & $3.00(1.38)$ & $5.33(2.64)$ & $1.55(0.77)$ & $2.20(1.07)$ \\
\hline 27 & $3.06(2.18)$ & $3.77(1.73)$ & $2.89(1.44)$ & $5.17(2.45)$ & $1.48(0.75)$ & $2.39(1.23)$ \\
\hline Trend & B ( $p$-value $)$ & B ( $p$-value $)$ & B ( $p$-value) & B ( $p$-value) & B ( $p$-value $)$ & B ( $p$-value) \\
\hline Age & $-0.28(<0.001)$ & $-0.19(0.142)$ & $-0.19(0.019)$ & $-0.65(<0.001)$ & $-0.029(0.419)$ & $-0.14(0.076)$ \\
\hline Age $^{2}$ & $0.007(<0.001)$ & $0.008(0.019)$ & $0.005(0.025)$ & $0.014(<0.001)$ & $0.001(0.291)$ & $0.003(0.085)$ \\
\hline
\end{tabular}

Legend: Cluster HIA: Higher Inflammatory Activation Cluster; Cluster LLWBC: Lowest Levels of WBC Cluster; Cluster HPEo: Highest Proportion of Eosinophils Cluster; Cluster LPEo: Lowest Proportion of Eosinophils Cluster; Cluster Un: Undefined Cluster. ${ }^{\text {a }}$ Absolute levels expressed as Total WBC $\times 10^{9} / \mathrm{L} .{ }^{\mathrm{b}}$ differential count expressed as relative percentage $(\%)$.

Table A2. Description of the total and differential white blood cells (WBC) at 13, 17, 21, 24 and 27 years of age according to the clusters.

\begin{tabular}{|c|c|c|c|c|c|c|}
\hline & $\begin{array}{c}\text { Total } \\
n=1183\end{array}$ & $\begin{array}{c}\text { Cluster HIA } \\
\quad n=163\end{array}$ & $\begin{array}{c}\text { Cluster } \\
L L W B C \\
n=136\end{array}$ & $\begin{array}{c}\text { Cluster HPEo } \\
n=285\end{array}$ & $\begin{array}{c}\text { Cluster LPEo } \\
n=344\end{array}$ & $\begin{array}{c}\text { Cluster } U n \\
n=238\end{array}$ \\
\hline Basophils b & Mean (SD) & Mean (SD) & Mean (SD) & Mean (SD) & Mean (SD) & Mean (SD) \\
\hline 13 & $0.40(0.42)$ & $0.36(0.20)$ & $0.29(0.16)$ & $0.46(0.27)$ & $0.25(0.13)$ & $0.58(0.38)$ \\
\hline 17 & $0.40(0.24)$ & $0.39(0.18)$ & $0.32(0.14)$ & $0.51(0.25)$ & $0.30(0.15)$ & $0.61(0.32)$ \\
\hline 21 & $0.41(0.25)$ & $0.43(0.21)$ & $0.33(0.16)$ & $0.49(0.24)$ & $0.30(0.16)$ & $0.60(0.30)$ \\
\hline 24 & $0.44(0.27)$ & $0.48(0.21)$ & $0.35(0.15)$ & $0.55(0.31)$ & $0.32(0.19)$ & $0.58(0.25)$ \\
\hline 27 & $0.42(0.26)$ & $0.45(0.24)$ & $0.32(0.14)$ & $0.50(0.27)$ & $0.32(0.16)$ & $0.59(0.31)$ \\
\hline Trend & $\mathrm{B}$ ( $p$-value $)$ & B ( $p$-value $)$ & $\mathrm{B}$ ( $p$-value $)$ & $\mathrm{B}$ ( $p$-value $)$ & B ( $p$-value $)$ & B ( $p$-value $)$ \\
\hline Age & $0.008(0.205)$ & $0.021(0.155)$ & $0.025(0.002)$ & $0.029(0.034)$ & $0.013(0.009)$ & $0.010(0.656)$ \\
\hline Age $^{2}$ & $<0.001(0.386)$ & $<0.001(0.443)$ & $<0.001(0.005)$ & $<0.001(0.066)$ & $<0.001(0.263)$ & $<0.001(0.606)$ \\
\hline Monocytes ${ }^{b}$ & Mean (SD) & Mean (SD) & Mean (SD) & Mean (SD) & Mean (SD) & Mean (SD) \\
\hline 13 & $7.22(1.96)$ & $6.52(1.11)$ & $7.50(1.63)$ & $7.19(2.21)$ & $6.41(1.29)$ & $8.86(2.29)$ \\
\hline 17 & $7.21(1.79)$ & $6.56(1.27)$ & $7.65(1.72)$ & $7.58(2.01)$ & $6.50(1.36)$ & $8.15(1.98)$ \\
\hline 21 & $8.31(2.00)$ & $7.82(1.60)$ & 8.57 (1.88) & 8.57 (1.99) & 7.52 (1.63) & $9.50(2.37)$ \\
\hline 24 & $8.23(2.08)$ & 7.85 (1.49) & $8.56(2.17)$ & $8.36(1.92)$ & 7.40 (1.59) & $9.44(2.56)$ \\
\hline 27 & $8.25(2.03)$ & $8.02(1.51)$ & $8.41(1.88)$ & $8.36(2.00)$ & $7.53(1.63)$ & $9.41(2.64)$ \\
\hline Trend & $\mathrm{B}$ ( $p$-value) & B ( $p$-value) & $\mathrm{B}(p$-value $)$ & $\mathrm{B}$ ( $p$-value) & $\mathrm{B}(p$-value $)$ & B ( $p$-value) \\
\hline Age & $0.34(<0.001)$ & $0.32(0.002)$ & $0.41(<0.001)$ & $0.48(<0.001)$ & $0.35(<0.001)$ & $-0.023(0.876)$ \\
\hline Age 2 & $-0.006(<0.001)$ & $-0.005(0.063)$ & $-0.008(<0.001)$ & $-0.010(<0.001)$ & $-0.006(<0.001)$ & $0.002(0.545)$ \\
\hline Lymphocytes ${ }^{b}$ & Mean (SD) & Mean (SD) & Mean (SD) & Mean (SD) & Mean (SD) & Mean (SD) \\
\hline 13 & $36.5(9.49)$ & $32.7(9.31)$ & $37.2(8.57)$ & $37.6(8.09)$ & $37.4(9.41)$ & $34.8(11.0)$ \\
\hline 17 & $35.8(8.15)$ & 32.7 (8.47) & $35.4(7.82)$ & $36.3(7.89)$ & $36.5(8.34)$ & $36.1(7.89)$ \\
\hline 21 & $34.6(7.93)$ & $30.1(6.42)$ & $35.1(6.88)$ & 34.7 (7.97) & $35.8(8.38)$ & $34.1(8.43)$ \\
\hline 24 & $34.4(8.03)$ & $31.0(6.24)$ & $34.2(7.18)$ & $34.3(7.95)$ & $35.9(8.46)$ & $33.4(8.65)$ \\
\hline 27 & $35.1(7.54)$ & $32.1(6.60)$ & $35.1(6.29)$ & $35.0(6.64)$ & $36.6(8.50)$ & $34.2(8.36)$ \\
\hline Trend & $\mathrm{B}$ ( $p$-value $)$ & $\mathrm{B}(p$-value $)$ & $\mathrm{B}(p$-value $)$ & B ( $p$-value $)$ & B ( $p$-value $)$ & $\mathrm{B}$ ( $p$-value) \\
\hline Age & $-1.03(<0.001)$ & $-1.42(0.014)$ & $-1.11(0.003)$ & $-1.31(0.001)$ & $-0.87(0.027)$ & $-0.26(0.650)$ \\
\hline Age $^{2}$ & $0.022(<0.001)$ & $0.033(0.210)$ & $0.020(0.040)$ & $0.027(0.007)$ & $0.020(0.040)$ & $0.003(0.826)$ \\
\hline
\end{tabular}

Legend: Cluster HIA: Higher Inflammatory Activation Cluster; Cluster LLWBC: Lowest Levels of WBC Cluster; Cluster HPEo: Highest Proportion of Eosinophils Cluster; Cluster LPEo: Lowest Proportion of Eosinophils Cluster; Cluster Un: Undefined Cluster. ${ }^{\mathrm{b}}$ differential count expressed as relative percentage $(\%)$.

\section{References}

1. Walker, D.M.; Slifka, M.K. Longevity of T-cell memory following acute viral infection. Adv. Exp. Med. Biol. 2010, 684, 96-107. [PubMed]

2. Zinkernagel, R.M. On immunological memory. Phil. Trans. R. Soc. Lond. B 2000, 355, 369-371. [CrossRef] [PubMed] 
3. Brodin, P.; Davis, M.M. Human immune system variation. Nat. Rev. Immunol. 2017, 17, 21-29. [CrossRef] [PubMed]

4. MacGillivray, D.M.; Kollmann, T.R. The role of environmental factors in modulating immune responses in early life. Front. Immunol. 2014, 5, 434. [CrossRef]

5. Divangahi, M.; Aaby, P.; Khader, S.A.; Barreiro, L.B.; Bekkering, S.; Chavakis, T.; van Crevel, R.; Curtis, N.; DiNardo, A.R.; Dominguez-Andres, J.; et al. Trained immunity, tolerance, priming and differentiation: Distinct immunological processes. Nat. Immunol. 2020, 22, 2-6. [CrossRef]

6. Grossman, Z.; Paul, W.E. Adaptive cellular interactions in the immune system: The tunable activation threshold and the significance of subthreshold responses. Proc. Natl. Acad. Sci. USA 1992, 89, 10365-10369. [CrossRef]

7. Liston, A.; Carr, E.J.; Michelle, A.; Linterman, M.A. Shaping Variation in the Human Immune System. Trends Immunol. 2016, 37, 637-646. [CrossRef]

8. Brodin, P.; Jojic, V.; Gao, T.; Bhattacharya, S.; Angel, C.L.; Furman, D.; Shen-Orr, S.; Dekker, C.L.; Swan, G.E.; Butte, A.J.; et al. Variation in the Human Immune System Is Largely Driven by Non-Heritable Influences. Cell 2015, 160, 37-47. [CrossRef] [PubMed]

9. Kaczorowski, K.J.; Shekhar, K.; Nkulikiyimfura, D.; Dekker, C.L.; Maecker, H.; Davis, M.M.; Chakraborty, A.K.; Brodin, P. Continuous immunotypes describe human immune variation and predict diverse responses. Proc. Natl. Acad. Sci. USA 2017, 114, E6097-E6106. [CrossRef]

10. O'Connor, M.F.; Bower, J.E.; Cho, H.J.; Creswell, J.D.; Dimitrov, S.; Hamby, M.E.; Hoyt, M.A.; Martin, J.L.; Robles, T.F.; Sloan, E.K.; et al. To assess, to control, to exclude: Effects of biobehavioral factors on circulating inflammatory markers. Brain Behav. Immun. 2009, 23, 887-897. [CrossRef]

11. Simon, A.K.; Hollander, G.A.; McMichael, A.J. Evolution of the immune system in humans from infancy to old age. Proc. R. Soc. B Biol. Sci. 2015, 282, 20143085. [CrossRef] [PubMed]

12. Viner, R.M.; Ozer, E.M.; Denny, S.; Marmot, M.; Resnick, M.; Fatusi, A.; Currie, C. Adolescence and the social determinants of health. Lancet 2012, 379, 1641-1652. [CrossRef]

13. Mangino, M.; Roederer, M.; Beddall, M.H.; Nestle, F.O.; Spector, T.D. Innate and adaptive immune traits are differentially affected by genetic and environmental factors. Nat. Commun. 2017, 8, 13850. [CrossRef]

14. Barroso, I.; Cabral, M.; Ramos, E.; Guimarães, J.T. Parental education associated with immune function in adolescence. Eur. J. Public Health 2020, 30, 444-448. [CrossRef] [PubMed]

15. Lawrence, G.M.; Friedlander, Y.; Calderon-Margalit, R.; A Enquobahrie, D.; Huang, J.Y.; Tracy, R.P.; Manor, O.; Siscovick, D.S.; Hochner, H. Associations of social environment, socioeconomic position and social mobility with immune response in young adults: The Jerusalem Perinatal Family Follow-Up Study. BMJ Open 2017, 7, e016949. [CrossRef]

16. McDade, T.W. Life history, maintenance, and the early origins of immune function. Am. J. Hum. Biol. 2005, 17, 81-94. [CrossRef]

17. Martino, D.; Allen, K. Meeting the challenges of measuring human immune regulation. J. Immunol. Methods 2015, 424, 1-6. [CrossRef] [PubMed]

18. Rivera, A.; Siracusa, M.C.; Yap, G.S.; Gause, W.C. Innate cell communication kick-starts pathogen-specific immunity. Nat. Immunol. 2016, 17, 356-363. [CrossRef]

19. Nalls, M.A.; Couper, D.J.; Tanaka, T.; van Rooij, F.J.A.; Chen, M.-H.; Smith, A.V.; Toniolo, D.; Zakai, N.A.; Yang, Q.; Greinacher, A.; et al. Multiple Loci Are Associated with White Blood Cell Phenotypes. PLoS Genet. 2011, 7, e1002113. [CrossRef]

20. Hato, T.; Dagher, P.C. How the Innate Immune System Senses Trouble and Causes Trouble. Clin. J. Am. Soc. Nephrol. 2015, 10, 1459-1469. [CrossRef]

21. Ramos, E.; Barros, H. Family and school determinants of overweight in 13-year-old Portuguese adolescents. Acta Paediatr. 2007, 96, 281-286. [CrossRef]

22. Magalhães, A.; Severo, M.; Autran, R.; Araújo, J.; Santos, P.; Pina, M.F.; Ramos, E. Validation of a Single Question for the Evaluation of Physical Activity in Adolescents. Int. J. Sport Nutr. Exerc. Metab. 2017, 27, 361-369. [CrossRef]

23. De Onis, M.; Onyango, A.W.; Borghi, E.; Siyam, A.; Nishida, C.; Siekmann, J. Development of a WHO growth reference for school-aged children and adolescents. Bull. World Health Organ. 2007, 85, 660-667. [CrossRef] [PubMed]

24. Yeh, E.; Willerson, J. Coming of age C-reactive protein. Using inflammation markers in cardiology. Circulation 2003, 107, 370-372. [CrossRef] [PubMed]

25. Pinheiro, J.C.; Bates, D.M. Mixed-Effects Models in S and S-PLUS; Springer: Berlin/Heidelberg, Germany, 2000.

26. Fraley, C.; Raftery, A.E. Model-based clustering, discriminant analysis and density estimation. J. Am. Stat. Assoc. 2002, 97, 611-631. [CrossRef]

27. Scrucca, L.; Fop, M.; Murphy, T.B.; Raftery, A.E. mclust 5: Clustering, Classification and Density Estimation Using Gaussian Finite Mixture Models. RJ 2016, 8, 205-233. [CrossRef]

28. Carr, E.; Dooley, J.; Garcia-Perez, J.E.; Lagou, V.; Lee, J.; Wouters, C.; Meyts, I.; Goris, V.L.A.; Boeckxstaens, G.; A Linterman, E.J.C.M.; et al. The cellular composition of the human immune system is shaped by age and cohabitation. Nat. Immunol. 2016, 17, 461-468. [CrossRef]

29. Yoshimura, A.; Ohnishi, S.; Orito, C.; Kawahara, Y.; Takasaki, H.; Takeda, H.; Sakamoto, N.; Hashino, S. Association of peripheral total and differential leukocyte counts with obesity-related complications in young adults. Obes. Facts 2015, 8, 1-16. [CrossRef]

30. Nieto, F.J.; Szklo, M.; Folsom, A.R.; Rock, R.; Mercuri, M. Leukocyte Count Correlates in Middle-aged Adults: The Atherosclerosis Risk in Communities (ARIC) Study. Am. J. Epidemiol. 1992, 136, 525-537. [CrossRef] 
31. Kullo, I.J.; Hensrud, D.D.; Allison, T.G. Comparison of numbers of circulating blood monocytes in men grouped by body mass index $(<25,25-<30, \geq 30)$. Am. J. Cardiol 2002, 89, 1441-1443. [CrossRef]

32. Grivennikov, S.I.; Greten, F.R.; Karin, M. Immunity, inflammation, and cancer. Cell 2010, 140, 883-899. [CrossRef]

33. Ait-Oufella, H.; Salomon, B.L.; Potteaux, S.; Robertson, A.K.L.; Gourdy, P.; Zoll, J.; Merval, R.; Esposito, B.; Cohen, J.L.; Fisson, S.; et al. Natural regulatory T cells control the development of atherosclerosis in mice. Nat. Med. 2006, 12, 178-180. [CrossRef]

34. Liu, X.; Zhang, Q.; Wu, H.; Du, H.; Liu, L.; Shi, H.; Wang, C.; Xia, Y.; Guo, X.; Li, C.; et al. Blood Neutrophil to Lymphocyte Ratio as a Predictor of Hypertension. Am. J. Hypertens. 2015, 28, 1339-1346. [CrossRef]

35. Imtiaz, F.; Shafique, K.; Mirza, S.S.; Ayoob, Z.; Vart, P.; Rao, S. Neutrophil lymphocyte ratio as a measure of systemic inflammation in prevalent chronic diseases in Asian population. Int. Arch. Med. 2012, 5, 2. [CrossRef] [PubMed]

36. Molina, A.; Vendrell, J.; Gutierrez, C.; Simón, I.; Masdevall, C.; Soler, J. Insulin resistance, leptin and TNF-alpha system in morbidly obese women after gastric bypass. Obes. Surg. 2003, 13, 615-621. [CrossRef] [PubMed]

37. Veronelli, A.; Laneri, M.; Ranieri, R.; Koprivec, D.; Vardaro, D.; Paganelli, M.; Folli, F.; Pontiroli, A.E. White Blood Cells in Obesity and Diabetes: Effects of weight loss and normalization of glucose metabolism. Diabetes Care 2004, 27, 2501-2502. [CrossRef]

38. Johannsen, N.M.; Priest, E.L.; Dixit, V.D.; Earnest, C.; Blair, S.N.; Church, T.S. Association of white blood cell subfraction concentration with fitness and fatness. Br. J. Sports Med. 2010, 44, 588-593. [CrossRef] [PubMed]

39. Johannsen, N.M.; Swift, D.L.; Johnson, W.D.; Dixit, V.D.; Earnest, C.P.; Blair, S.N.; Church, T.S. Effect of Different Doses of Aerobic Exercise on Total White Blood Cell (WBC) and WBC Subfraction Number in Postmenopausal Women: Results from DREW. PLoS ONE 2012, 7, e31319. [CrossRef] [PubMed]

40. Willis, E.A.; Shearer, J.J.; Matthews, C.E.; Hofmann, J.N. Association of physical activity and sedentary time with blood cell counts: National Health and Nutrition Survey 2003-2006. PLoS ONE 2018, 13, e0204277. [CrossRef]

41. Pitsavos, C.; Panagiotakos, D.B.; Chrysohoou, C.; Kavouras, S.; Stefanadis, C. The associations between physical activity, inflammation, and coagulation markers, in people with metabolic syndrome: The ATTICA study. Eur. J. Cardiovasc. Prev. Rehabil. 2005, 12, 151-158. [CrossRef]

42. Claycombe, K.; King, L.E.; Fraker, P.J. A role for leptin in sustaining lymphopoiesis and myelopoiesis. Proc. Natl. Acad. Sci. USA 2008, 105, 2017-2021. [CrossRef] [PubMed]

43. Stone, K.D.; Prussin, C.; Metcalfe, D.D. IgE, mast cells, basophils, and eosinophils. J. Allergy Clin. Immunol. 2010, 125 (Suppl. 2), S73-S80. [CrossRef] [PubMed]

44. Ramirez, G.A.; Yacoub, M.R.; Ripa, M.; Mannina, D.; Cariddi, A.; Saporiti, N.; Ciceri, F.; Castagna, A.; Colombo, G.; Dagna, L. Eosinophils from Physiology to Disease: A Comprehensive Review. Biomed. Res. Int. 2018, 2018, 9095275. [CrossRef] [PubMed]

45. Wen, T.; Rothenberg, M.E. The Regulatory Function of Eosinophils. Microbiol. Spectr. 2016, 4, 257-269. [CrossRef]

46. Chirumbolo, S. State-of-the-art review about basophil research in immunology and allergy: Is the time right to treat these cells with the respect they deserve? Blood Transfus. 2012, 10, 148-164.

47. Tsang, J.S. Utilizing population variation, vaccination, and systems biology to study human immunology. Trends Immunol. 2015, 36, 479-493. [CrossRef] [PubMed]

48. Prescott, S.L. Early-life environmental determinants of allergic diseases and the wider pandemic of inflammatory noncommunicable diseases. J. Allergy Clin. Immunol. 2013, 131, 23-30. [CrossRef] 